\title{
Determination of low level exposure to volatile aromatic hydrocarbons and genotoxic effects in workers at a styrene plant
}

\author{
O Holz, G Scherer, S Brodtmeier, F Koops, K Warncke, T Krause, A Austen, J Angerer, \\ A R Tricker, F Adlkofer, $H$ W Rüdiger
}

\begin{abstract}
Objectives-Low exposures to volatile aromatic hydrocarbons and cytogenetic effects in peripheral white blood cells were determined in 25 healthy workers employed in different areas of a styrene production plant in the former German Democratic Republic. The results were compared with 25 healthy unexposed

to styrene, benzene, and ethylbenzene did not induce alterations of genotoxicological variables except kinetochore positive micronuclei. This is the first reported use of the CREST technique for an in vivo study in occupational toxicology, which thus could serve as a valuable and sensitive technique for toxicogenic monitoring.
\end{abstract} controls (matched for age and sex) employed in the same company.

Methods-The concentrations of aromatic hydrocarbons determined from active air sampling in all areas of the factory (styrene: 73-3540 $\mu \mathrm{g} / \mathrm{m}^{3} \quad(<0.01-0.83 \mathrm{ppm})$; ethylbenzene $365-2340 \mu \mathrm{g} / \mathrm{m}^{3}(0.08-0.53 \mathrm{ppm})$; benzene 73-3540 $\mu \mathrm{g} / \mathrm{m}^{3}$ (<0.02-1.11 $\left.\mathrm{ppm}\right)$; toluene $54-2960 \mu \mathrm{g} / \mathrm{m}^{3} \quad(0.01-0.78 \mathrm{ppm})$; xylenes $\left.12-94 \mu \mathrm{g} / \mathrm{m}^{3} \quad(<0.01-0.02 \mathrm{ppm})\right)$ were considerably lower than in the pump house $\left(>4000 \mu \mathrm{g} / \mathrm{m}^{3}\right.$ styrene, ethylbenzene, benzene, and toluene; $>500 \mu \mathrm{g} / \mathrm{m}^{3}$ xylenes), which was only intermittently occupied for short periods. Passive personal monitoring, biomonitoring of exhaled air and metabolites (mandelic, phenylglyoxylic, trans, trans-muconic, hippuric, $o-, m-$ and $p$-methylhippuric acids, and phenol) in urine samples collected before and after an eight hour working shift was used to assess individual exposure. Questionnaires and examination of company records showed that the historical exposure was far higher than that measured. Genotoxic monitoring was performed by nuclease P1-enhanced ${ }^{32} \mathbf{P}$-postlabelling of DNA adducts in peripheral blood monocytes, and DNA single strand breaks, sister chromatid exchange, and micronuclei in lymphocytes. The content of kinetochores in the micronuclei was determined by immunofluorescence with specific antibodies from the serum of CREST patients.

Results-No genotoxic effects related to exposure were detected by DNA adducts or DNA single strand breaks and sister chromatid exchange. The only effect related to exposure was an increase in kinetochore positive micronuclei in peripheral lymphocytes; the frequency of total micronuclei in peripheral lymphocytes did not change. Smoking was confirmed by measurement of plasma cotinine, and no confounding effect was found on any of the cytogenetic variables. Conclusions-Low occupational exposure
(Occup Environ Med 1995;52:420-428)

Keywords: volatile aromatic hydrocarbons; genotoxic monitoring; kinetochore positive micronuclei

Occupational exposure to benzene is associated with cytogenetic abnormalities and an increased risk of leukaemia in humans. ${ }^{1}$ For alkylbenzenes such as toluene and xylenes, inadequate evidence exists for their carcinogenicity in experimental animals and humans. ${ }^{2}$

Styrene has mutagenic properties that are principally attributed to its main active metabolite, styrene-7,8-oxide. ${ }^{3}$ Styrene acts directly in vitro inducing sister chromatid exchange ${ }^{4}$ and chromosomal aberrations ${ }^{5}$ in human whole blood cultures. In workers exposed to styrene, styrene-7,8-oxide adducts have been detected in DNA isolated from lymphocytes ${ }^{6-8}$ and in haemoglobin. ${ }^{9}$ Cross sectional occupational studies have shown increased sister chromatid exchange in lymphocytes of workers exposed to concentrations of styrene of at least $170-213 \mathrm{mg} / \mathrm{m}^{3},{ }^{11}{ }^{12}$ but at lower exposures no increase is found. ${ }^{913}$ Similarly, increases in chromosomal aberrations in lymphocytes are only observed with exposure to relatively high concentrations $\left(112-435 \mathrm{mg} / \mathrm{m}^{3}\right)$ of styrene. ${ }^{14}$ In stimulated lymphocytes without cytokinesis block, significant increases in the percentage of micronucleated lymphocytes have been detected in workers exposed to styrene at $47-55 \mathrm{mg} / \mathrm{m}^{3} .{ }^{915}$ At concentrations as low as $11 \mathrm{ppm}(0 \cdot 6-44$ ppm), significant increases in DNA single strand breaks in lymphocytes occur. ${ }^{9}$ A summary of genotoxicological studies on styrene exposure has recently been published. ${ }^{10}$ Despite the range of cytogenetic effects induced by exposure to styrene, no epidemiological data are available to support an increased risk of cancer in workers exposed to styrene.

Ethylbenzene is devoid of biological activity in the Ames test and genotoxicity in both experimental in vitro systems ${ }^{16}$ and animal 
models. ${ }^{17}$ Neither the United States Environmental Protection Agency nor the International Agency for Research on Cancer has classified ethylbenzene as having carcinogenic potential, because of lack of data.

Toluene on its own is devoid of biological activity and does not induce mutations in the Ames test, or sister chromatid exchange, or chromosomal aberrations in experimental in vitro systems. ${ }^{18}$ Cytogenetic effects found in workers exposed to both toluene and benzene are most probably due to benzene, and it is doubtful whether toluene induces somatic cell damage in humans. ${ }^{18}$

Xylenes are also devoid of biological activity and do not induce mutations in the Ames test $^{20}$ or micronucleation in bone marrow polychromatic erythrocytes after being given intraperitoneally to mice. ${ }^{17}$ Xylenes do not induce sister chromatid exchange or chromosomal aberrations in human lymphocytes in vitro $^{21}$ or cytogenetic effects in lymphocytes of human volunteers after experimental exposure to $174 \mathrm{mg} / \mathrm{m}^{3}$ of xylene $(15 \% \circ-, 25 \% \mathrm{p}$-, and $60 \% m$-xylene) for seven hours a day over three consecutive days. ${ }^{22}$

In our study, the effect of low occupational exposure to a mixture of styrene, ethylbenzene, benzene, toluene, and xylenes in 25 styrene production workers and 25 nonexposed controls employed at a styrene production plant in the former German Democratic Republic is reported. Exposure was determined by passive and personal air sampling for each subject, biomonitoring of aromatic hydrocarbons in exhaled air, and excretion of urinary metabolites. Cytogenetic studies are reported in which both the short and long term effects of exposure to low concentrations of these aromatic hydrocarbons are determined with nuclease P1-enhanced ${ }^{32} \mathrm{P}$-postlabelling of DNA adducts in peripheral blood monocytes as well as DNA single strand breaks, sister chromatid exchange, and micronucleation in lymphocytes. The influence of smoking as a possible confounding factor of genotoxic effects is also reported.

\section{Materials and methods SUBJECTS}

The study was conducted over one working week in July 1991 in a styrene production plant in the former German Democratic Republic. Twenty five exposed workers (mean age $38 \cdot 8$, range $20-58$ ) were compared with 25 non-exposed control employees (mean age $39 \cdot 3$, range 19-59) working at the same company. All subjects were matched for age and sex (17 men and eight women). Information was obtained by questionnaire concerning diet, cigarette and alcohol consumption, use of medication, and possible exposure to aromatic hydrocarbons outside the workplace. Occupational histories and historical exposure were evaluated by examination of company records. The exposed workers were employed in five different areas of the styrene production plant (oven house, production control; storage facility, distillation area, pump house) and the non-exposed controls in the company medical service, fire brigade, and the security service that manned the factory gates.

The questionnaire showed that the average time of employment of the 25 exposed workers in the plant was 18 years with a historic exposure of one to 34 years. The smoking habits were similar: exposed group, 13 smokers (mean 15.2 cigarettes/day, range 4-40); control group, 17 smokers (mean $17 \cdot 1$ cigarettes/day, range 10-25). Determination of plasma cotinine, a nicotine metabolite, confirmed the similarity of both study groups (exposed smokers $v$ control smokers: 280 (202) v 243 (132) $\mathrm{ng}$ cotinine/ml plasma). Apart from the self reported tendency for higher consumption of alcohol in the nonexposed control group, no further noteworthy differences were apparent from the questionnaires.

\section{EXPOSURE MEASUREMENT}

Air samples were collected with graphitised charcoal tubes (type 1-010R2, Analyt GmbH, Mühlheim, Germany) and a model PCXR7 SKC aircheck sampler (DEHA Haan and Wittmer GmbH, Friolzheim, Germany). Intermittent sampling (one minute sample collection every 10 minutes) at a flow rate of $100 \mathrm{ml} / \mathrm{min}$ over a period of one hour was performed at each of the five site areas (net sampling time six minutes a tube) and for three hours at each of the workplaces of the controls (18 minutes a tube). Analysis of aromatic hydrocarbons was performed by microwave desorption (Rektorik, Geneva, Switzerland) directly into a gas chromatograph-mass spectrometer (GC-MS; HP 5890/-MSD 5870, Hewlett-Packard $\mathrm{GmbH}$, Bad Homburg, Germany). The limit of detection was $1 \mu \mathrm{g} / \mathrm{m}^{3}$.

Personal exposure to aromatic hydrocarbons was determined by passive sampling with ORSA 5 personal samplers (Dräger AG, Lübeck, Germany). Personal samplers were worn by each subject over the entire eight hour working shift and styrene, ethylbenzene, benzene, and toluene were measured by the standard NIOSH method. ${ }^{24}$

\section{COLLECTION AND ANALYSIS OF EXHALED}

SAMPLES

Samples exhaled after the shift were collected on graphitised charcoal tubes (type 1-010R2, Analyt $\mathrm{GmbH}$ ) for two minutes at a flow rate of $0.5 \mathrm{ml} / \mathrm{min}$ with a modified sampling device. ${ }^{25}$ Analysis of coded samples under blind conditions was performed by microwave desorption GC-MS.

COLLECTION AND ANALYSIS OF URINE SAMPLES Urine samples were collected from each subject at the beginning and end of the working shift. Metabolites of styrene and ethylbenzene (mandelic and phenylglyoxylic acids, benzene (phenol), toluene (hippuric acid), and xylenes (o-, $m$-, and $p$-methylhippuric acids), were measured by methods published by the Analytical Chemistry Working Group of the Deutsche Forschungsgemeinschaft Commission 
for the investigation of health hazards of chemical compounds in the work area. ${ }^{26}$ Trans,trans-muconic acid, another benzene metabolite, was measured by the method of Ducos. ${ }^{27}$ Urinary concentrations were expressed after correction for creatinine, which was determined by the Jaffé method with a commercial kit (Merck, Darmstadt, Germany). All samples were coded and analysed under blind conditions.

\section{COLLECTION OF BLOOD SAMPLES FOR}

GENOTOXIC STUDIES

Blood samples $(50 \mathrm{ml})$ were drawn from the cubital vein into coded heparinised syringes at the end of the working shift. Samples were transported in ice to the laboratory with as little vibration as possible. White blood cells for genotoxic studies were isolated within four to five hours of sample collection. Blood samples were also used to confirm smoking state by measurement of cotinine in plasma with a modified radioimmunoassay. ${ }^{28}$

NUCLEASE P1-ENHANCED 32P-POSTLABELLING OF DNA ADDUCTS IN MONOCYTES

White blood cells were isolated from $5 \mathrm{ml}$ of whole blood by a modified Ficoll-Paque density centrifugation. ${ }^{29}$ Isolated leucocytes were cultured and monocytes purified from residual lymphocytes for ${ }^{32} \mathrm{P}$-postlabelling. ${ }^{30}$ The DNA was isolated by proteinase $\mathrm{K}$ digestion ${ }^{31}$ and was measured by fluorescence spectrometry with calf thymus DNA (Boehringer Mannheim GmbH, Germany) as a standard. ${ }^{32}$ The postlabelling method was adjusted to the detection of benzene related DNA adducts. ${ }^{33}$ The DNA samples ( $8 \mu \mathrm{g}$ DNA) were evaporated to dryness and digested overnight at $37^{\circ} \mathrm{C}$ in a total volume of $7 \mu \mathrm{l}$ containing $0.21 \mathrm{U}$ micrococcal nuclease (Sigma, Deisenhofen, Germany), $0.58 \mathrm{mU}$ spleen phosphodiesterase (Boehringer Mannheim $\mathrm{GmbH}), 17 \mathrm{mM}$ disodium succinate, and $8 \mathrm{mM} \mathrm{CaCl}_{2}$. Nucleotides were measured by the absorbance at $260 \mathrm{~nm}$ of a $2 \mu \mathrm{l}$ aliquot of the digest. ${ }^{34}$ The digest was treated with $5 \mu \mathrm{l}$ of an aqueous solution containing nuclease P1 (1 U; Sigma), sodium acetate $(0 \cdot 12 \mathrm{M})$, and $\mathrm{ZnCl}_{2}(0.09 \mathrm{mM})$. The samples were incubated at $37^{\circ} \mathrm{C}$ for one hour and the reaction terminated by adding $2 \mu \mathrm{l}$ of $0.5 \mathrm{M}$ tris base. The DNA samples $(5 \mu \mathrm{l})$ were labelled with ${ }^{32} \mathrm{P}$ by adding $25 \mu \mathrm{l}$ of labelling buffer (200 $\mathrm{mM}$ bicine, $100 \mathrm{mM} \mathrm{MgCl}_{2}, 100 \mathrm{mM}$ dithiothreitol, $10 \mathrm{mM}$ spermidine), $25 \mu \mathrm{l}$ of carrier free $\left[\gamma-{ }^{32} \mathrm{P}\right] \mathrm{ATP}(20 \mu \mathrm{Ci}$; Amersham Buchler, Braunschweig, Germany), 7.5 $\mu 1$ T4 polynucleotide kinase (6.7 U; Boehringer Mannheim $\mathrm{GmbH}$ ) and $13.4 \mu \mathrm{l} \mathrm{H}_{2} \mathrm{O}$ and labelled nucleotides resolved by four dimensional chromatography on PEI cellulose thin layer chromatography (TLC) sheets (Macherey-Nagel, Düren, Germany). ${ }^{33}$ The adducts were detected by screen intensified autoradiography for 72 hours at $80^{\circ} \mathrm{C}$ (Xomat 5, Kodak, Rochester, NY, USA). The radioactive areas were excised and the radioactivity measured by scintillation spectrometry. Adduct concentrations, expressed as relative adduct labelling were calculated from adduct count rates and the specific activity of $\left[\gamma-{ }^{32} \mathrm{P}\right]$ ATP.${ }^{35}$ The specific activity of $[\gamma-$ ${ }^{32}$ P]ATP was determined by measuring incorporation of ${ }^{32} \mathrm{P}$ into $1 \mathrm{pmol}$ of deoxyadenosine 3'-monophosphate (dAp). The $\mathrm{dAp}$ was labelled in exactly the same way as the samples and diluted in $1.5 \mathrm{ml}$ bicine (200 $\mathrm{mM}$ ) before it was put on the TLC sheet. The $\left[\gamma-{ }^{32} \mathrm{P}\right] \mathrm{ATP}$ was excised after onedimensional chromatography $(\mathrm{pH} 6.8 ; 0.28$ $\mathrm{M}$ ammonium sulphate, $0.05 \mathrm{M}$ disodium hydrogen phosphate). The amount of deoxyribonucleoside 5 '-monophosphates (dNp) on the chromatograms was calculated with the estimate that $1 \mu \mathrm{g}$ DNA $=3240 \mathrm{pmol}$ DNA-P. A calibration curve was constructed with known amounts of digested DNA to determine the exact amounts of sample digest. The adduct nucleotides in three areas of the chromatogram (A, B, C), and the remaining area (D), except for radioactive areas to the top and side of the origin (fig), were excised and counted. Two aliquots of one sample of DNA were labelled and the average amount of radioactivity of the two autoradiograms was calculated.

\section{LYMPHOCYTE MICRONUCLEUS ASSAY}

Lymphocytes were isolated from $5 \mathrm{ml}$ of whole blood by a Ficoll-Paque density centrifugation $^{29}$ and washed twice with $\mathrm{pH} 7 \cdot 2$ phosphate buffered saline (PBS). Micronucleated lymphocytes were measured with a modified cytokinesis-block method. ${ }^{36}$ Cells were cultured at $37^{\circ} \mathrm{C}$ for 72 hours in $5 \mathrm{ml}$ of chromosome medium 1A (Gibco, Karlsruhe, Germany) that contained $10 \mathrm{ml} / 1$ phytohaemagglutinin. Cytochalasin B $(3 \mu \mathrm{g} / \mathrm{ml}$ final concentration; Sigma) was added after 44 hours of incubation. After 72 hours cells were washed in hypotonic saline for eight minutes, fixed in methanol/glacial acetic acid (4:1), and harvested on to slides. Slides were dried and stained for 15 minutes in 4',6-diamidino-2phenylindole (DAPI, $5 \mathrm{mg} / \mathrm{l}$; Serva Feinbiochemica, Heidelberg, Germany). Two thousand binucleated cells per sample were scored blindly by the same reader. Micronuclei had to meet the following criteria: (a) DAPI positive, (b) less than one third the diameter of the main nucleus, $(c)$ in the same plane of focus, $(d)$ have the same texture as the main nucleus, and $(e)$ have a smooth oval or round shape.

\section{IMMUNOFLUORESCENT STAINING OF} KINETOCHORE POSITIVE MICRONUCLEI

Kinetochore positive micronuclei were determined by CREST antibody labelling. ${ }^{37}$ Cultures for determination of kinetochore positive micronuclei were established as already described. After culture, cells were fixed with ethanol (95\%), washed with PBS (pH 7.2), and collected by centrifugation (10 minutes, $140 \mathrm{~g}$ ). Cells were transferred to a $1.5 \mathrm{ml}$ vial, resuspended in $1 \mathrm{ml}$ calcinosisRaynaud's phenomenon-oesophageal dismobility-sclerodactyly-telangiectasia syndrome of scleroderma (CREST; Chemicon 

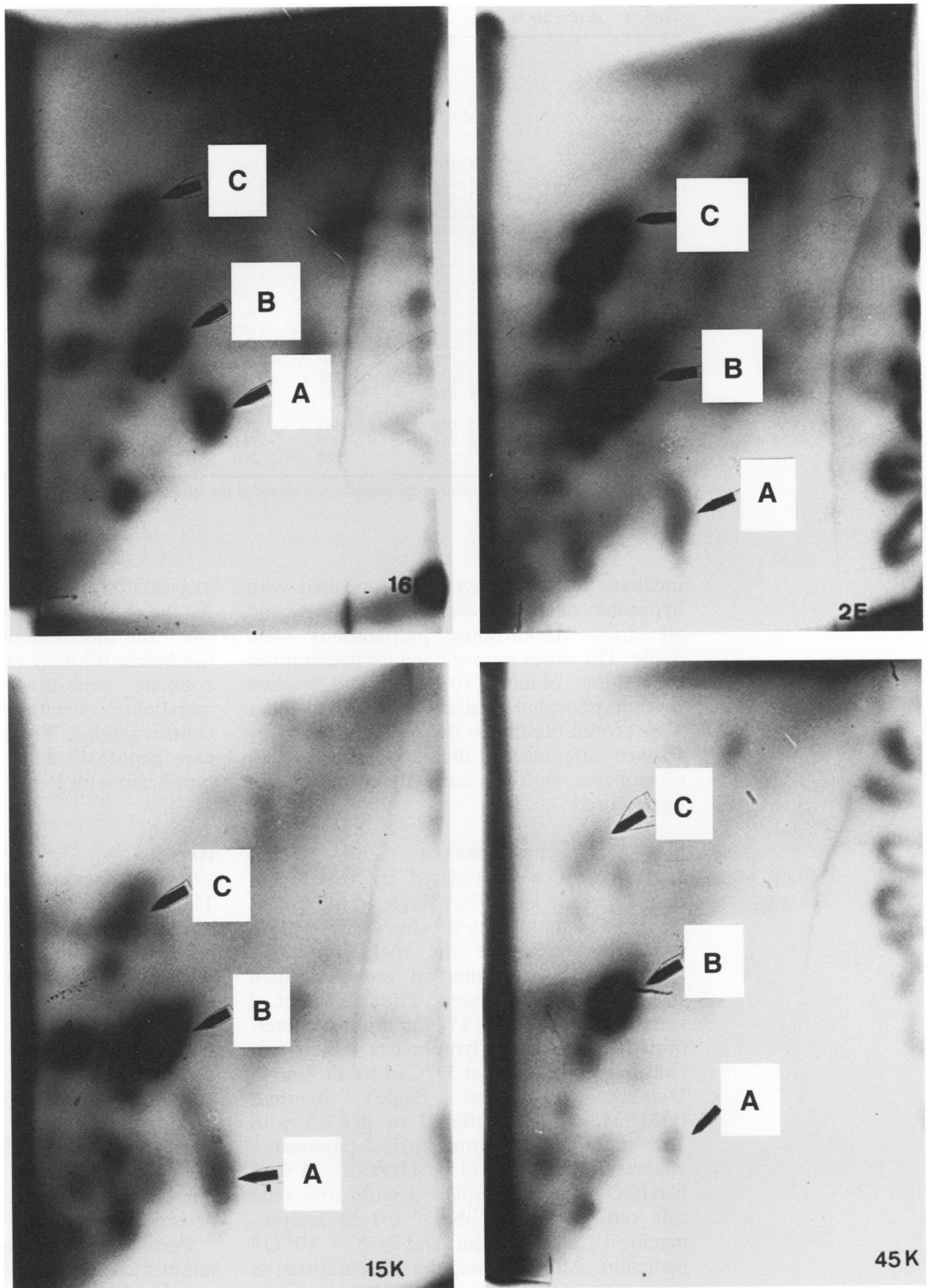

Representative ${ }^{32} P$-postlabelling autoradiograms of peripheral monocyte DNA adducts in exposed people (top) and controls (bottom). The areas $A, B$, and $C$ represent areas with adduct nucleotides that were separately evaluated (table 4).

International, Temecula, CA, USA) antibody solution (CREST serum 1:500 diluted with pH 7.2 PBS containing $1 \%$ albumin) and incubated at $37^{\circ} \mathrm{C}$ for one hour. Cells were centrifuged (three minutes, $550 \mathrm{~g}$ ), washed twice with PBS containing $1 \%$ albumin and incubated at $37^{\circ} \mathrm{C}$ for 45 minutes in $1 \mathrm{ml}$ of rhodamine conjugated rabbit-antihuman IgG (1:500 diluted with $\mathrm{pH} 7 \cdot 2$ PBS containing $1 \%$ albumin). Cells were harvested on to slides and stained with DAPI, then immersed for 20 seconds in dansylchloride $(0.3 \mathrm{mg} / \mathrm{ml}$, 2:1 $\mathrm{NaHCO}_{3}$ saturated ethanol/0.9\% $\mathrm{NaCl}$ ) to make the cytoplasm visible. Two thousand binucleated cells per sample were scored blindly by the same reader for kinetochore positive micronuclei.

\section{SISTER CHROMATID EXCHANGE}

Whole blood $(1 \mathrm{ml})$ cultures were established in $5 \mathrm{ml}$ of chromosome medium 1A (Gibco) that contained $15 \mu \mathrm{g} / \mathrm{ml}$ 5-bromo-2-deoxyuridine (BrdUrd). Cultures were incubated for 72 hours at $37^{\circ} \mathrm{C}$ under conditions of dim light. Colcemid $(0 \cdot 1 \mu \mathrm{g} / \mathrm{ml})$ was added to each culture two hours before the end of 
Table 1 Active air sampling of aromatic hydrocarbons at different working sites

\begin{tabular}{|c|c|c|c|c|c|c|c|}
\hline \multirow[b]{2}{*}{$\begin{array}{l}\text { Exposure group } \\
\text { and location }\end{array}$} & \multirow[b]{2}{*}{$\begin{array}{l}\text { Time } \\
\text { period }\end{array}$} & \multicolumn{6}{|c|}{ Concentrations of aromatic hydrocarbon at different workplaces $\left(\mu \mathrm{g} / \mathrm{m}^{3}\right)$} \\
\hline & & Styrene & $\begin{array}{l}\text { Ethyl- } \\
\text { benzene }\end{array}$ & Benzene & Toluene & o-Xylene & $\begin{array}{l}m \text {-or } \\
p \text {-Xylene }\end{array}$ \\
\hline \multicolumn{8}{|l|}{ Exposed workers: } \\
\hline Oven house & $\begin{array}{l}0921-1021 \\
1021-1121 \\
1121-1221\end{array}$ & $\begin{array}{l}200 \\
220 \\
355\end{array}$ & $\begin{array}{r}940 \\
1090 \\
1120\end{array}$ & $\begin{array}{l}325 \\
210 \\
725\end{array}$ & $\begin{array}{l}150 \\
175 \\
265\end{array}$ & $\begin{array}{r}9 \cdot 5 \\
14 \cdot 7 \\
18 \cdot 8\end{array}$ & $\begin{array}{l}12 \cdot 5 \\
17 \cdot 1 \\
15 \cdot 7\end{array}$ \\
\hline Production control & $\begin{array}{l}0927-1027 \\
1030-1130 \\
1130-1230\end{array}$ & $\begin{array}{r}810 \\
2570 \\
505\end{array}$ & $\begin{array}{r}835 \\
1360 \\
420\end{array}$ & $\begin{array}{r}2320 \\
950 \\
970\end{array}$ & $\begin{array}{r}1010 \\
655 \\
710\end{array}$ & $\begin{array}{l}8.5 \\
8 \cdot 1 \\
6.0\end{array}$ & $\begin{array}{l}42 \cdot 1 \\
11 \cdot 9 \\
64 \cdot 0\end{array}$ \\
\hline Storage facility & $\begin{array}{l}0921-1021 \\
1027-1127 \\
1127-1227\end{array}$ & $\begin{array}{r}73 \\
265 \\
235\end{array}$ & $\begin{array}{r}670 \\
1180 \\
1230\end{array}$ & $\begin{array}{r}340 \\
1570 \\
2280\end{array}$ & $\begin{array}{c}25 \cdot 5 \\
250 \\
54 \cdot 1\end{array}$ & $\begin{array}{r}6 \cdot 5 \\
13 \cdot 4 \\
17 \cdot 6\end{array}$ & $\begin{array}{r}5 \cdot 6 \\
5 \cdot 5 \\
23 \cdot 2\end{array}$ \\
\hline Distillation area & $\begin{array}{l}1244-1344 \\
1344-1444 \\
1444-1544\end{array}$ & $\begin{array}{l}3040 \\
3540 \\
1840\end{array}$ & $\begin{array}{r}365 \\
2340 \\
1440\end{array}$ & $\begin{array}{l}2230 \\
3260 \\
2120\end{array}$ & $\begin{array}{l}2850 \\
2960 \\
2200\end{array}$ & $\begin{array}{l}44 \cdot 1 \\
30 \cdot 6 \\
15.3\end{array}$ & $\begin{array}{r}50.0 \\
6.2 \\
40.9\end{array}$ \\
\hline Pump house* & $\begin{array}{l}1444-1544 \\
1231-1331 \\
1331-1431 \\
1431-1531\end{array}$ & $\begin{array}{l}1840 \\
>4000 \\
>4000 \\
>4000\end{array}$ & $\begin{array}{l}1440 \\
>4000 \\
>4000 \\
>4000\end{array}$ & $\begin{array}{l}2120 \\
>4000 \\
>4000 \\
>4000\end{array}$ & $\begin{array}{l}2200 \\
>4000 \\
>4000 \\
>4000\end{array}$ & $\begin{array}{l}15 \cdot 3 \\
>300 \\
>300 \\
>300\end{array}$ & $\begin{array}{l}40 \cdot 9 \\
>500 \\
>500 \\
>500\end{array}$ \\
\hline \multicolumn{8}{|l|}{ Control workers: } \\
\hline Medical centre & $1605-1820$ & $49 \cdot 2$ & 290 & 180 & 85 & $15 \cdot 6$ & $21 \cdot 2$ \\
\hline Fire station & $1332-1635$ & $11 \cdot 7$ & 145 & $58 \cdot 7$ & 125 & $16 \cdot 6$ & $18 \cdot 3$ \\
\hline Security office & $1021-1321$ & $38 \cdot 8$ & 250 & $67 \cdot 1$ & $47 \cdot 1$ & $15 \cdot 5$ & $16 \cdot 8$ \\
\hline
\end{tabular}

^All measurements performed within the pump house exceeded the sampling capacity of the sampling device.

incubation. Lymphocytes were washed with hypotonic saline, harvested on to slides, and air dried chromosome preparations were made. The slides were stained for five minutes in acridine orange $(10 \mu \mathrm{g} / \mathrm{ml})$ and washed twice in phosphate buffer ( $\mathrm{pH} 6 \cdot 0$ ). All slides were scored blindly by the same reader. Only 15 well differentiated diploid second division metaphases with at least 40 chromosomes were scored.

\section{DNA SINGLE STRAND BREAKS}

Lymphocytes were isolated by the FicollPaque method and DNA single strand breaks determined immediately afterwards with a modified version of the nick translation assay. ${ }^{38}$ Each determination was performed seven times and averaged. The coefficient of variation was below $15 \%$ for multiple determinations. A second lymphocyte sample was cultured for 12 hours at $37^{\circ} \mathrm{C}$ in sterile filtered Dulbecco's modified Eagle's medium (DMEM, Gibco) buffered to $\mathrm{pH} 7.5$ with $20 \mathrm{mM}$ 4-(2-hydroxyethyl)-1-piperazineethanesulphonic acid (HEPES), $1.0 \mathrm{~g} / 1$ $\mathrm{NaHCO}_{3}$ and supplemented with $10 \%$ fetal calf serum (FCS; Gibco), $0.1 \mathrm{~g} / 1$ streptomycin, $0.1 \mathrm{~g} / 1$ neomycin, and $7.78 \times 10^{4} \mathrm{U} / 1$ penicillin. After culture, the nick translation assay was performed to determine the capacity of DNA for repair.

\section{STATISTICAL ANALYSIS}

As the individual groupings were sometimes small and the distributions not always normal, the Mann-Whitney rank sum test was used to compare exposure, alveolar, and urinary metabolite concentrations in the exposed and control groups. The $t$ test was used to compare genotoxic data. A test was considered significant with $P<0.05$.

\section{Results}

EXPOSURE ASSESSMENT

Table 1 shows the concentrations of aromatic hydrocarbons in ambient air of the different production plant areas (oven house, production control, storage facility, distillation area, pump house) and control working areas (medical centre, fire station, security office). Active air sampling showed the maximum concentrations within the pump house, where only a few workers were present for short periods. The concentrations of aromatic hydrocarbons were significantly higher than in the control areas and in the case of the pump house exceeded the upper limit of the detection method.

Personal monitoring with ORSA 5 passive samples confirmed that the workers were exposed to far higher concentrations of aromatic hydrocarbons (styrene $0.31 \quad(0.88) \mathrm{ppm}$;

Table 2 Aromatic hydrocarbon concentrations in exhaled air after the shift

\begin{tabular}{|c|c|c|c|c|c|c|c|}
\hline \multirow[b]{2}{*}{ Exposure group } & \multirow[b]{2}{*}{$\begin{array}{l}\text { Subjects } \\
n\end{array}$} & \multicolumn{6}{|c|}{ Concentrations of aromatic hydrocarbon in exhaled air after the shift (mean (SD) $\mu g / m^{3}$ ) } \\
\hline & & Styrene & $\begin{array}{l}\text { Ethyl- } \\
\text { benzene }\end{array}$ & Benzene & Toluene & o-Xylene & $\begin{array}{l}m \text {-or } \\
p \text {-Xylene }\end{array}$ \\
\hline \multicolumn{8}{|l|}{ Exposed workers: } \\
\hline Total group & 25 & $83.9(167.6)^{\star \star}$ & $95 \cdot 5(78 \cdot 2)^{\star \star \star}$ & $30 \cdot 9(17 \cdot 0)^{\star \star \star}$ & $25.5(9 \cdot 8)^{\star \star \star}$ & $3 \cdot 4(1 \cdot 3)$ & \\
\hline Smokers & 17 & $79.9(188.1)$ & $104.0(91.2)$ & $27 \cdot 2(14 \cdot 5)^{\star \star}$ & $21 \cdot 8$ & $3 \cdot 5(1 \cdot 3)$ & $3.5(1.8)$ \\
\hline $\begin{array}{l}\text { Non-smokers } \\
\text { Non-exposed controls: }\end{array}$ & 8 & $92 \cdot 4(112 \cdot 1)$ & $77 \cdot 5(31 \cdot 1)$ & $38 \cdot 8(19 \cdot 1)^{\star \star}$ & $23.9(11 \cdot 1)^{\star}$ & $3 \cdot 3(1 \cdot 3)$ & $4.0(2 \cdot 4)$ \\
\hline \multicolumn{2}{|c|}{ Non-exposed controls: } & $30.2(52.0)$ & $20.7(10.8)$ & $5.5(3.8)$ & $14 \cdot 3(11 \cdot 2)$ & 3.5 & $4.0(2.5)$ \\
\hline $\begin{array}{l}\text { 10tal goup } \\
\text { Smokers }\end{array}$ & 13 & $25.3(44.8)$ & $20.3(6.5)$ & $7.6(3.8)$ & $\begin{array}{l}14.3(11.2) \\
17.8(14.5)\end{array}$ & 3.6( & $3.8(2.2)$ \\
\hline Non-smokers & 12 & $35.5(58.4)$ & $21 \cdot 2(14 \cdot 1)$ & $3.2(2.0)$ & $10.6(2.7)$ & $3 \cdot 4(2 \cdot 4)$ & $4 \cdot 2(2 \cdot 8)$ \\
\hline
\end{tabular}

${ }^{\star} \mathrm{P}<0.05 ;{ }^{\star \star} \mathrm{P}<0.01 ;{ }^{\star \star \star} \mathrm{P}<0.001$; paired differences between exposed and unexposed groups for individual aromatic hydrocarbons by Mann-Whitney rank sum test. 
Table 3 Aromatic hydrocarbon metabolites in urine

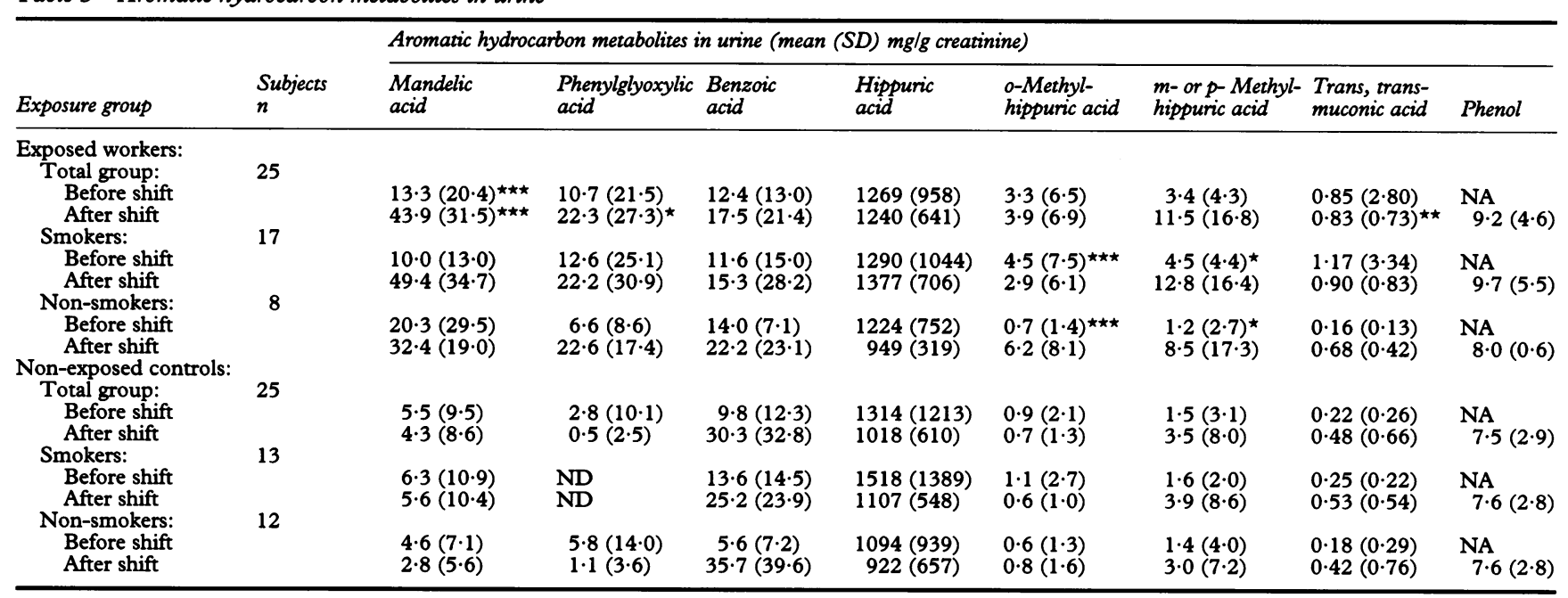

${ }^{\star} \mathrm{P}<0.05 ;{ }^{\star \star} \mathrm{P}<0.01 ;{ }^{\star \star \star} \mathrm{P}<0.001$; paired differences between exposed and unexposed group for individual aromatic hydrocarbon metabolites by Mann-Whitney rank sum test.

$\mathrm{ND}=$ not detected; NA = not analysed.

ethylbenzene $1.51(3.42) \mathrm{ppm}$; benzene 0.24 $(0.24) \mathrm{ppm}$ ) than were controls (all $<0.004(0.02) \mathrm{ppm})$. Toluene exposure, however, was higher in the controls (1.31 (2.68) $\mathrm{ppm})$ than in the exposed workers $(0.79$ $(1.97) \mathrm{ppm})$. Individual xylene isomers were not determined.

\section{BIOMONITORING OF EXHALED AROMATIC} HYDROCARBONS

Analysis of exhaled air after the shift confirmed that workers in the production areas were exposed to significantly $(P \leqslant 0.001)$ higher concentrations of all aromatic hydrocarbons except for xylenes (table 2). In the control group, smoking had a significant confounding effect on exhaled benzene ( $P=$ $0.007)$ and toluene $(P=0.021)$, but not on the concentrations of other aromatic hydrocarbons in the exhaled air of exposed workers.

A significant positive correlation between personal air monitoring and exhaled benzene (Pearson's coefficient $r=0.51 ; \mathrm{P}=0.01$ ) was found. Non-significant or negative correlations were obtained for styrene $(r=0.31)$, ethylbenzene $(r=0.23)$, and toluene $(r=$ $-0 \cdot 13)$.

BIOMONITORING OF AROMATIC HYDROCARBON METABOLITES IN URINE

In comparison with the control workers (table 3), metabolite concentrations in urine sampled after the shift in the exposed workers showed significantly higher exposure to styrene and ethylbenzene (mandelic acid $P<0.001$; phenylglyoxylic acid $P=0.03$ ) and benzene (trans, trans-muconic acid $\mathrm{P}=$ $0.003)$, but not $o-, m$-, or $p$-xylenes $(o-, m$-, or $p$-methylhippuric acids). Comparison of urine samples before and after the shift also showed a significant exposure of workers to styrene and ethylbenzene (mandelic acid $\mathrm{P}<$ 0.001 ; phenylglyoxylic acid $P=0.06$ ), but not to benzene, toluene, and xylenes. No significant confounding effect due to smoking was evident. The urinary excretion of $m$ - and $p$ methylhippuric acid was higher before the shift in smokers than in non-smokers in the exposed group. This was only just significant $(P=0.049)$.

DNA ADDUCTS IN MONOCYTES

No significant increase in total or segregated monocyte DNA adducts (figure), measured as relative adduct concentrations, were present in the exposed workers (table 4). Considerable variability between individual workers, but no exposure related or confounding effects due to smoking, was detected.

\section{LYMPHOCYTE MICRONUCLEUS ASSAY}

The frequency of micronucleated lymphocytes was not significantly different in exposed and control workers (table 5). Smokers in both groups showed lower but not significantly

Table 4 DNA adducts in peripheral monocytes

\begin{tabular}{|c|c|c|c|c|c|c|}
\hline \multirow[b]{2}{*}{ Exposure group } & \multirow{2}{*}{$\begin{array}{l}\text { Subjects } \\
n\end{array}$} & \multicolumn{5}{|c|}{ Monocyte DNA adducts or relative adduct concentration (mean (SD)) } \\
\hline & & Area $A$ & Area $B$ & Area $C$ & Area $D$ & Total \\
\hline \multicolumn{7}{|l|}{ Exposed workers: } \\
\hline $\begin{array}{l}\text { Total group } \\
\text { Smokers } \\
\text { Non-smokers }\end{array}$ & $\begin{array}{r}25 \\
17 \\
8\end{array}$ & $\begin{array}{l}4 \cdot 17(2 \cdot 76) \\
4 \cdot 45(3.04) \\
3.52(2.06)\end{array}$ & $\begin{array}{l}13.67(8 \cdot 74) \\
14.67(9.82) \\
11.38(5.52)\end{array}$ & $\begin{array}{l}15.13(9.93) \\
16.22(10.84) \\
12.64(7.60)\end{array}$ & $\begin{array}{l}41.78(24 \cdot 61) \\
41 \cdot 11(26 \cdot 60) \\
43.32(21 \cdot 16)\end{array}$ & $\begin{array}{l}74 \cdot 7(42 \cdot 8) \\
76 \cdot 4(46 \cdot 6) \\
70 \cdot 9(35 \cdot 7)\end{array}$ \\
\hline Control workers: & & & & & & \\
\hline $\begin{array}{l}\text { Total group } \\
\text { Smokers } \\
\text { Non-smokers }\end{array}$ & $\begin{array}{l}25 \\
13 \\
12\end{array}$ & $\begin{array}{l}3.76(2.39) \\
3.47(2.06) \\
4.08(2.77)\end{array}$ & $\begin{array}{l}11.90(7 \cdot 36) \\
10.67(5.56) \\
13.24(8.98)\end{array}$ & $\begin{array}{l}10.38(6.8) \\
10.06(6.33) \\
10.74(7.55)\end{array}$ & $\begin{array}{l}36.75(25 \cdot 4) \\
35.57(25 \cdot 34) \\
38.04(26.54)\end{array}$ & $\begin{array}{l}62 \cdot 8(38 \cdot 9) \\
59 \cdot 8(37 \cdot 7) \\
66 \cdot 1(41 \cdot 7)\end{array}$ \\
\hline
\end{tabular}


Table 5 Micronucleus assay in lymphocytes

\begin{tabular}{|c|c|c|c|}
\hline Exposure group & $\begin{array}{l}\text { Subjects } \\
n\end{array}$ & $\begin{array}{l}\text { Binucleate cells } \\
\text { with micronuclei(\%) } \\
\text { (mean (SD)) }\end{array}$ & $\begin{array}{l}\text { Kinetochore positive } \\
\text { micronuclei(\%) } \\
\text { (mean (SD)) }\end{array}$ \\
\hline $\begin{array}{l}\text { Exposed workers } \\
\text { Total group } \\
\text { Smokers } \\
\text { Non-smokers }\end{array}$ & $\begin{array}{r}25 \\
17 \\
8\end{array}$ & $\begin{array}{l}1.90(0.78) \\
1.84(0.61) \\
2.03(1.11)\end{array}$ & $\begin{array}{l}39 \cdot 43(10 \cdot 22)^{\star \star} \\
38 \cdot 25(11.26)^{\star} \\
42 \cdot 14(7.36)^{\star}\end{array}$ \\
\hline $\begin{array}{l}\text { Control workers: } \\
\text { Total group } \\
\text { Smokers } \\
\text { Non-smokers }\end{array}$ & $\begin{array}{l}25 \\
13 \\
12\end{array}$ & $\begin{array}{l}1.87(0.71) \\
1.61(0.62) \\
2.15(0.71)\end{array}$ & $\begin{array}{l}31 \cdot 79(8 \cdot 15) \\
30 \cdot 25(7 \cdot 85) \\
33.33(8 \cdot 49)\end{array}$ \\
\hline
\end{tabular}

${ }^{\star} \mathrm{P}<0.05 ;{ }^{\star} \mathrm{P}<0.01$ paired differences between exposed and unexposed group (kinetochore positive micronuclei only) by $t$ test.

Table 6 Sister chromatid exchange in lymphocytes

\begin{tabular}{lll}
\hline Exposure group & $\begin{array}{l}\text { Subjects } \\
n\end{array}$ & $\begin{array}{l}\text { Sister chromatid } \\
\text { exchange/cell (mean (SD)) }\end{array}$ \\
\hline Exposed workers: & & \\
$\quad$ Total group & 25 & $9 \cdot 27(1 \cdot 24)$ \\
$\quad$ Smokers & 17 & $9.38(1.37)$ \\
$\quad$ Non-smokers & 8 & $9.04(0.99)$ \\
Control workers: & & \\
Total group & 25 & $9 \cdot 24(1 \cdot 24)$ \\
$\quad$ Smokers & 13 & $9.67(1.36)$ \\
$\quad$ Non-smokers & 12 & $8.87(0.96)$ \\
\hline
\end{tabular}

different frequencies of micronuclei than their non-smoking counterparts. Significantly higher proportions of kinetochore positive micronuclei were found in the total exposed working group $(P=0.007)$, exposed smokers $(P=0.045)$, and exposed non-smokers $(P=0.035)$. The proportion of kinetochore positive micronuclei was also lower in smokers in both the exposed and control groups when compared with their non-smoking counterparts. This difference was not significant.

\section{SISTER CHROMATID EXCHANGE IN LYMPHOCYTES}

The frequency of sister chromatid exchange was almost identical in the exposed workers and controls (table 6). Slight, but not significant, increases were found in smokers compared with non-smokers in both the exposed and control groups.

DNA SINGLE STRAND BREAKS IN LYMPHOCYTES No significant differences in DNA single strand breaks in lymphocytes were found between the exposed and control workers (table 7), and smoking had no effect. Significant repair of DNA single strand breaks

Table 7 DNA single strand breaks in lymphocytes

\begin{tabular}{llll}
\hline & Subjects & \multicolumn{2}{l}{ DNA single strand breaks (cpm, relative) mean (SD) } \\
\cline { 3 - 4 } Exposure group & $n$ & $5 h$ after sampling & 17 h after sampling \\
\hline Exposed workers: & 25 & $2370(1063)^{\star \star \star}$ & $1137(441)^{\star \star \star}$ \\
$\quad$ Total group & 17 & $2185(882)^{\star \star \star}$ & $1160(498)^{\star \star \star}$ \\
$\quad$ Smokers & 8 & $2763(1358)^{\star \star}$ & $1089(311)^{\star \star}$ \\
$\quad$ Non-smokers & 8 & $2550(988)$ & $1247(393)$ \\
Control workers: & 25 & $2530(987)$ & $1255(362)$ \\
$\quad$ Total group & 13 & $2572(1034)$ & $1240(441)$ \\
$\quad$ Smokers & 12 & Non-smokers &
\end{tabular}

${ }^{\star} \mathrm{P}<0.05 ;{ }^{\star \star} \mathrm{P}<0.01 ;{ }^{\star \star \star} \mathrm{P}<0.00$ paired differences between exposed and unexposed group $(5 \mathrm{~h}$ and $17 \mathrm{~h}$ after sampling) by $t$ test.
$(P<0.003)$ occurred when lymphocytes from both the exposed and control workers were kept for an additional 12 hours in culture. The repair capacity was not reduced in smokers when compared with non-smokers.

\section{Discussion}

Personal monitoring showed that exposure to all aromatic hydrocarbons with the exception of toluene and xylenes (not determined) was higher in the exposed workers. Comparison of exhaled air after the shift confirmed that the exposed workers were exposed to significantly higher concentrations of styrene, ethylbenzene, benzene, and toluene (all $P<0.001$ ). As in other studies, ${ }^{39-41}$ smoking had a significant confounding effect in the control group on the exhaled concentrations of benzene (non-smokers $3.2(2.0) \mu \mathrm{g} / \mathrm{m}^{3}$; smokers 7.6 (3.8) $\mu \mathrm{g} / \mathrm{m}^{3} ; \quad \mathrm{P}=0.007$ ) and toluene (nonsmokers $10.6 \quad(2.7) \mu \mathrm{g} / \mathrm{m}^{3}$; smokers 17.8 $\left.(14.5) \mu \mathrm{g} / \mathrm{m}^{3} ; \quad P=0.021\right)$, but not in the exposed group. As analysis of exhaled air is a sensitive biomonitoring method for toluene and xylene, ${ }^{42}$ it is evident (table 2) that the workers had little or no exposure to xylenes above background concentrations.

In the exposed working group, urine samples taken after the shift, corrected for creatinine, contained significantly higher concentrations of phenylglyoxylic acid $(P=0.03)$, mandelic acid ( $P<0.001)$, and trans, transmuconic acid $(P=0.003)$ providing further confirmation of combined occupational exposure to styrene, ethylbenzene, and benzene. The increase found in trans, transmuconic acid is only partially in agreement with other studies in which both trans, transmuconic acid and phenol are reported to be unsuitable for biomonitoring low benzene exposures ( $<1 \mathrm{ppm}) .^{27} 4344$

Considerable variability between individual workers, but no increase in DNA adducts related to exposures was detected in peripheral blood monocytes (figure), which suggests that sources unrelated to the low occupational exposure to aromatic hydrocarbons may have been responsible for the adduct concentrations found (table 4). Monocytes have a biological half life of eight hours in peripheral blood $^{45}$ and are metabolically competent to activate aromatic xenobiotics. ${ }^{46}$ Consequently, relative adduct labelling in monocytes represents recent rather than historical exposure. None of the detected adducts corresponded to DNA adducts formed in vitro by incubation of calf thymus DNA with hydroquinone or benzoquinone - two DNA reactive metabolites of benzene. No relation was found between the relative adduct concentrations and exposure to individual or total aromatic hydrocarbons.

No significant differences were found in the frequency of micronuclei in lymphocytes between the exposed and control workers (table 5). The only difference found was a significant increase in the proportion of kinetochore positive micronuclei in the total exposed working group $(P=0.007)$, exposed 
smokers $(P=0.045)$, and exposed nonsmokers $(P=0.035)$. In the cytokinesis-block method $^{36}$ that we used, blastogenesis of $\mathrm{T}$ lymphocytes stimulated by phytohaemagglutinin provides a means of assessing cytogenetic effects due to long term (historical) exposure as $T$ cells are not always found in the peripheral vasculature, have a half life in excess of four years, and may last in extravascular tissue compartments for extended periods. Micronuclei represent small, additional nuclei formed by the exclusion of chromosome fragments (kinetochore negative micronuclei) or whole chromosomes (kinetochore positive micronuclei) lagging at mitosis. The CREST staining technique is highly effective in distinguishing agents that induce aneuploidy from clastogens in human lymphocytes. ${ }^{37}$ As the frequency of total micronuclei and kinetochore positive micronuclei was lower in smokers than in non-smokers in the control group, although not significantly (total micronuclei $\mathrm{P}=0.056$; kinetochore positive micronuclei $P=0.366$ ), it can only be concluded that the increase in the proportion of kinetochore positive micronuclei in the exposed workers is directly related to occupational exposure to either aromatic hydrocarbons or some other unidentified agent that induces aneuploidy. Although styrene and styrene-7,8-oxide induce micronuclei in human lymphocytes, ${ }^{47}$ the increased proportion of kinetochore positive micronuclei is more consistent with an indirect genotoxic effect due to benzene metabolites. ${ }^{48}$ In contrast with most studies in which structural chromosomal aberrations have been found in workers with current benzene exposure, studies that detected aneuploidy have generally been performed on people with diagnosed bone marrow toxicity some time after benzene exposure had ceased. ${ }^{49} 50$ This is the first reported use of the CREST technique to study kinetochore positive micronuclei in occupationally exposed workers. This reported increase in kinetochore positive micronuclei is particularly significant as very recent studies have shown that both hydroquinone ${ }^{51}$ and 1,2,4-trihydroxybenzene, ${ }^{52}$ two metabolites of benzene, induce aneuploidy, a chromosomal defect often detected in leukaemia. ${ }^{53}$

The frequency of sister chromatid exchange in lymphocytes was almost identical in the exposed and control workers (table 6). Previous investigations on exposure to low concentrations of benzene and other aromatic hydrocarbons have produced conflicting results in which either an increase, ${ }^{54} 55$ or no change in the frequency of sister chromatid exchange has been reported..$^{225657}$

No significant differences in DNA single strand breaks in lymphocytes were found in the exposed and control workers (table 7), as DNA is modified at an estimated rate of $10^{5}$ bases per cell per day in the absence of exogenous damage. ${ }^{58}$ In contrast with conventional techniques to detect DNA single strand breaks, the nick translation assay allows the detection of in situ DNA single strand breaks in intact cells. ${ }^{38}$ Numbers of DNA single strand breaks were first determined five hours after blood sampling during which time repair of some of the lesions occurred. This was evident from lymphocytes that were kept in culture for a further 12 hours before performing the nick translation assay. Five to 17 hours after drawing the blood samples, significant $(P<0.003)$ repair of lesions was still evident. With conventional alkaline elution techniques to detect DNA single strand breaks, exposure to styrene $(11.2(0.9) \mathrm{ppm}){ }^{9}$ benzene $(4.2$ $(4 \cdot 2) \mathrm{ppm})$, and toluene $(70 \text { (66) } \mathrm{ppm})^{19}$ results in significant increases in DNA single strand breaks in lymphocytes. Both these studies did not investigate possible repair effects. Our results indicate that DNA lesions are not induced by exposure to low concentrations of aromatic hydrocarbons and that lesions present are subject to repair. Furthermore, the capacity for repair is not compromised in smokers.

In summary, low exposure to volatile aromatic hydrocarbons was determined in workers who produce styrene and was compared with a non-exposed control group by air monitoring and biomonitoring techniques. Short term genotoxic effects of exposure were not detected in the form of DNA adducts in peripheral blood monocytes, DNA single strand breaks, and sister chromatid exchanges in lymphocytes. A long term increase in kinetochore positive micronuclei, but not total micronuclei (related to exposure) was found in peripheral lymphocytes, which is consistent with exposure to benzene. Smoking had no confounding effect on any of the measured cytogenetic variables.

This work was supported by the German Ministry of Research and Technology (BMFT) Grant No 01HK098/4.

1 International Agency for Research on Cancer. Monographs on the evaluation of carcinogenic risk to humans. Overall evaluations of carcinogenicity: an updating of IARC monographs vols 1 to 42 . Lyon: IARC, 1987 (suppl 7);120-2.

2 International Agency for Research on Cancer. Monographs on the evaluation of carcinogenic risk to humans, vol 47, some organic solvents, resin monomers and related compounds, pigments and occupational exposures in paint manupacture and painting. IARC, Lyon: 1989.

3 Barale R. The genetic toxicology of styrene and styrene oxide. Mutat Res 1991;257:107-26.

4 Norppa H, Sorsa M, Pfaffi P, Vainio H. Styrene and styrene oxide induce SCEs and are metabolized in human lymphocyte cultures. Carcinogenesis 1980;1: 357-61.

5 Jantunen K, Maki-Paakkanen J, Norppa H. Induction of chromosome aberrations by styrene and vinylacetate in cultured human lymphocytes: dependence on erythrocyltured Mutat Res 1986;159:109-16.

6 Liu SF, Rappaport SM, Pongracz K, Bodell WJ. Detection of styrene oxide-DNA adducts in lymphocytes of a worker exposed to styrene. In: Bartsch H, Hemminki K, W'Neill IK, eds. Methods for detecting DNA damaging O'Neill IK, eds. Methods for detecting DNA damaging agents in humans: applications in cancer epidemiology and
prevention, vol 89. Lyon: International Agency for

7 Bodell WJ, Pongracz K, Kaur S, Burlingame AL, Liu SF Rappaport SM. Investigation of styrene oxide-DNA adducts and their detection in workers exposed to styrene. Environ Mol Mutagen 1989;14(suppl 15):25.

8 Vodicka P, Vodickova L, Hemminki K. ${ }^{32}$ P-postlabeling of DNA adducts of styrene-exposed lamination workers. Carcinogenesis 1993;14:2059-61.

9 Brenner DB, Jeffrey AM, Latriano L, Wazneh L, Warburton $\mathrm{D}$, Toor $\mathrm{M}$, et al. Biomarkers in styreneexposed boatbuilders. Mutat Res 1991;261:225-36.

10 International Agency for Research on Cancer. Monographs on the evaluation of carcinogenic risks to humans, vol 60. on the evaluation of carcinogenic risks to huma.
Some Industrial Chemicals. Lyon: IARC, 1994. 
11 Andersson HC, Tranberg EA, Uggla AH, Zetterburg G. Chromosomal aberrations and sister-chromatid exchanges in lymphocytes of men occupationally exposed to styrene in a plastic-boat factory. Mutat Res 1980;73:387-401.

12 Camurri L, Codeluppi S, Pedroni C, Scarduelli L. Chromosome aberrations and sister-chromatid exchanges in workers exposed to styrene. Mutat Res 1983;119:361-9.

13 Hansteen I-L, Jelmert O, Torgrimsen T, Forsund B. Low human exposure to styrene in relation to chromosome human exposure to styrene in relation to chromosome
breaks, gaps and sister chromatid exchanges. Hereditas breaks, gaps and

14 Tomanin R, Ballarin C, Bartolucci GB, De Rosa E, Sessa $G$, Iannini $G$, et al. Chromosome aberrations and micronuclei in lymphocytes of workers exposed to low and medium levels of styrene. Int Arch Occup Environ Health 1992;64:209-15.

15 Högstedt B, Äkesson B, Axell K, Gullberg B, Mitelman F, Pero RW, et al. Increased frequency of lymphocyte micronuclei in workers producing reinforced polyester resin with low exposure to styrene. Scand $\mathcal{F}$ Work Environ Health 1983;9:241-6.

16 Von Burg R. Ethylbenzene. F Appl Toxicol 1992;12:69-71.

17 Mohtashamipur E, Norpoth K, Woelke U, Huber P. Effects of ethylbenzene, toluene and xylene on the Effects of ethylbenzene, toluene and xylene on the
induction of micronuclei in bone marrow polychromatic induction of micronuclei in bone marrow polychrom

$18 \mathrm{McGregor} \mathrm{D}$. The genetic toxicology of toluene. Mutat Res 1994;317:213-28.

19 Popp W, Vahrenholz C, Yaman S, Müller C, Müller G, Schmieding $\mathrm{W}$, et al. Investigations of the frequency of DNA strand breakage and cross-linking and of sister chromatid exchange frequency in the lymphocytes of female workers exposed to

20 Carcinogenesis 1992;13:57-61. Henderson PT. Non-mutagenicity of toluene, $0-, m$ - and H-xylene, $o$-methylbenzylsulphate in the Ames assay. p-xylene, o-methylbenzyls

21 Gerner-Smidt P, Friedrich U. The mutagenic effect of benzene, toluene and xylene studied by the SCE technique. Mutat Res 1978;58:313-6.

22 Richer C-L, Chakrabarti S, Senécal-Quevillon M, Duhr MA, Zhang XX, Tardiff R. Cytogenetic effects of lowlevel exposure to toluene, xylene, and their mixture on human blood lymphocytes. Int Arch Occup Environ Health 1993;64:581-5.

24 NIOSH. Manual of analytical methods. Method 1500/1501. Cincinnati: US Department of Health and Human Services. 1984;1:84-100.

25 Raymer J, Thomas KW, Cooper SD, Whitaker DA Pellizzari ED. A device for sampling of human alveolar breath for the measurement of expired volatile organic breath for the measurement of expired volatile
compounds. ₹ Anal Toxicol 1990;14:337-44.

26 Angerer J, Schaller KH. Analysis of hazardous substances in biological materials, vol 2. Mannheim: VCH Verlagsgesellschaft, 1988

27 Ducos P, Gaudin R, Robert A, Francin JM, Maire C. Improvement in HPLC analysis of urinary trans, transmuconic acid, a promising substitute for phenol in the assessment of benzene exposure. Int Arch Occup Environ Health 1990;62:529-34.

28 Langone J, Gjika HB, Van Vunakis H. Nicotine and its metabolites: radioimmunoassay for nicotine and cotimetabolites: radioimmunoassay for

29 Boyum A. Separation of lymphocytes, lymphocyte subgroups and monocytes. A review. Lymphology 1977; 10:71-6.

30 Holz O, Krause T, Rüdiger HW. Differences in DNA adduct formation between monocytes and lymphocytes after in vivo incubation with benzo(a)pyrene. Carcinogenesis 1991;12:2181-3.

31 Leadon SA, Cerutti PA. A rapid and mild procedure for isolation of DNA from mammalian cells. Anal Biochem 1982;120:282-8.

32 Fiszer-Szafarz B, Szafalz D, Guevara A, De Murillo AG. A general, fast, and sensitive micromethod for DNA determination: application to rat and mouse liver, rat determination: application to rat and mouse liver, rat hepatoma, human leukocytes, chicken fibrob

33 Randerath K, Randerath E, Danna TF, van Golen KL, Putman KL. A new sensitive ${ }^{32} \mathrm{P}$-postlabeling assay based on the specific enzymatic conversion of bulky DNA lesions to radiolabeled dinucleotides and nucleoside 5'-monophosphates. Carcinogenesis 1989; 10:1231-9.

34 Reddy MV, Blackburn GR, Schreiner CA, Mehlman MA, Mackerer CR. ${ }^{32} \mathrm{P}$-Analysis of DNA adducts in tissues of benzene-treated rats. Environ Health Perspect 1989; 82:253-7.

35 Reddy MV, Randerath K. Nuclease P1-mediated enhancement of sensitivity of ${ }^{32} \mathrm{P}$-postlabeling test for structurally diverse DNA adducts. Carcinogenesis 1986;7:1543-51. 36 Fenech $M$. The cytokinesis-block micronucleus assay in nucleated cells. Prog Clin Biol Res 1990;340B:195-206.

37 Eastmond DA, Tucker JD. Identification of aneuploidyinducing agents using cytokinesis-blocked human lymphocytes and an antikinetochore antibody. Environ Mol Mutagen 1989;13:34-43.

38 Krause T, Einhaus M, Holz O, Meißner R, Baumgartner $E$, Rüdiger $H W$. A novel technique for the detection of DNA single-strand breaks in human white blood cells and its combination with the unscheduled DNA synthesis assay. Int Arch Occup Environ Health 1993;65:77-82.

39 Brugnone F, Perbellini L, Faccini GB, Pasini F, Maranelli $\mathrm{G}$, Romeo $\mathrm{L}$, et al. Breath and blood levels of benzene, toluene, cumene and styrene in non-occupational exposure. Int Arch Occup Environ Health 1989;61:303-11.

40 Krotoszynski BK, Bruneau GM, O'Neill HJ. Measurement of chemical inhalation exposure in urban populations in the presence of endogenous effluents. $\mathcal{F}$ Anal Toxicol 1979;3:225-34.

41 Perbellini L, Faccini GB, Pasini F, Cazzoli F, Pistoia S, Rosellini $R$, et al. Environmental and occupational exposure to benzene by analysis of breath and blood. $\mathrm{Br} F$ Ind Med 1988;45:345-52.

42 Laparé $S$, Tardiff $R$, Brodeur J. Effect of various exposure scenarios on the biological monitoring of organic solvents in alveolar air. I. Toluene and $m$-xylene. Int Arch vents in Environ Health 1993;64:569-80.

43 Rauscher D, Lehnert G, Angerer J. Biomonitoring of occupational exposure and environmental exposure to benzene by measuring trans, trans-muconic acid in urine. Clin Chem 1994;40:1468-70.

44 Bechtold WE, Lucier G, Birnbaum LS, Yin SN, Li GL, Henderson RF. Muconic acid determination in urine as a biological exposure index for workers occupationally exposed to benzene. Am Ind Hyg Assoc F 1991;52:473-8.

45 Meuret G. Human monocytopoiesis. Exp Hematol 1974;2:238-49.

46 Bast RC Whitlock JP, Miller H, Rapp HJ, Gelboin HV. Aryl hydrocarbon (benzo(a)pyrene) hydroxylase in human peripheral blood monocytes. Nature 1974; human peripl

47 Norppa H, Vainio H. Genetic toxicity of styrene and some of its derivatives. Scand $\mathcal{f}$ Work Environ Health 1983; 9:108-14.

48 Yager JW, Eastmond DA, Robertson ML, Paradisin WM, Smith MT. Characterization of micronuclei induced in human lymphocytes by benzene metabolites. Cancer Res 1990;50:393-9.

49 Liniecki J, Bajerska A, Gluszczowa M. Analiza kariologiczna limfocytow krwi obwodowej u osob z przebytym zatruciem benzenem [The effects of passed chronic benzene poisoning upon the karyotype of peripheral benzene poisoning upon the karyotype of
blood lymphocytes]. Med $\operatorname{Pr} 1971 ; 22: 187-93$.

50 Ding X, Li Y, Ding Y, Yang H. Chromosome changes in patients with chronic benzene poisoning. Chin Med ff (Engl) 1983;96:681-5

51 Eastmond DA, Rupa DS, Hasegawa LS. Detection of hyperdiploidy and chromosome breakage in interphase human lymphocytes following exposure to the benzene metabolite hydroquinone using multicolor fluorescence in situ hybridization with DNA probes. Mutat Res 1994;322:9-20.

52 Zhang L, Venkatesh P, Robertson Creek ML, Smith MT Detection of 1,2,4-benzenetriol induced aneuploidy and microtubule disruption by fluorescence in situ hybridizamicrotubule disruption by fluorescence in situ hybridiza-
tion and immunocyto-chemistry. Mutat Res 1994;320: tion and

53 Losada AP, Wessman M, Tiainen M, Hopman AHN, Willard HF, Sole F, et al. Trisomy 12 in chronic ymphocyte leukemia: an interphase cytogenetic study. Blood 1991;78:775-9.

54 Yager JW, Paradisin WM, Rappaport SM. Sister-chromatid exchanges in lymphocytes are increased in relation to longitudinally measured occupational exposure to low
concentrations of styrene. Mutat Res 1993;319:155-65.

55 Major J, Jakob M, Kiss G, Tompa A. Chromosome aberration, sister-chromatid exchange, proliferative rate index, and serum thiocyanate concentration in smokers and serum thiocyanate concentration in smokers exposed to low-dos

56 Kelsey KT, Smith TJ, Hammond SK, Letz R, Little JB. Sister-chromatid exchanges in lymphocytes from styrene-exposed boat builders. Mutat Res 1990;241 215-21.

57 Sarto F, Cominato I, Pinton AM, Brovedani PG, Merler $\mathrm{E}$, Peruzzi $\mathrm{M}$, et al. A cytogenetic study on workers exposed to low concentrations of benzene. Carcinogenesis 1984;5:827-32.

58 Saul RL, Ames BN. Background levels of DNA damage in the population. In: Simic M, Grossmann L, Upton A, eds. Mechanisms of DNA damage and repair. New York: Plenum, 529-35. 